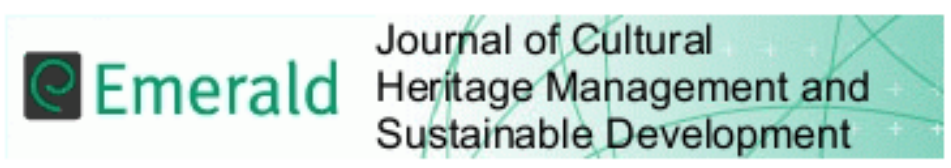

\title{
Social entrepreneurship for sustainable heritage management - The case of Open-Air museums
}

\begin{tabular}{|r|l|}
\hline Journal: & Journal of Cultural Heritage Management and Sustainable Development \\
\hline Manuscript ID & JCHMSD-02-2019-0010 \\
\hline Manuscript Type: & Research Paper \\
\hline Keywords: & $\begin{array}{l}\text { Open-air museums, Heritage crafts, intangible cultural heritage, social } \\
\text { entrepreneurship, sustainable heritage management, management tool }\end{array}$ \\
\hline \multicolumn{2}{|l}{}
\end{tabular}

\section{SCHOLARONE \\ Manuscripts}




\title{
Social entrepreneurship for sustainable heritage management - The case of Open-Air museums
}

\begin{abstract}
:
The overarching purpose of this study was to identify the specific potentials of Open-air museum and heritage crafts cooperation by using Social Entrepreneurial approaches as a sustainable growth enabler. The study utilised literature, reports, questionnaires, interviews and two in-depth case studies to examine the extent and success of current cooperation and the barriers to success affecting both fields on their own. Finally, the study utilised the recently developed social entrepreneurial tool the "modified Social Entrepreneurial Problem and Objective tree (mSEPOT)" in order to test the model's ability to analyse a real world case and demonstrate solutions and improvement to future cooperation in a heritage context. While the tool has not been validated in practice, the study offers the first conceptualization of utilizing the tool arguing that innovative future approaches to sustainable heritage development are possible and that heritage managers in the MSEPOT have a tool enabling them to engage with social entrepreneurial approaches, ensuring sustainability of development projects in culture and heritage.
\end{abstract}

Key-words: Open-air museums, Heritage crafts, intangible cultural heritage, social entrepreneurship, sustainable heritage management, sustainable cultural product (SCP), sustainable cultural project, management tool.

\section{Introduction}

Cultural heritage is in a protracted crisis evident in their ever diminishing public financing (Matero et al. 2013; Loulanski 2007; MacDonald \& Alsford 1995; Ross 2004). Museums and heritage sites across the spectre are feeling the economic squeeze and suffering the consequences. New approaches to economic and cultural development are needed but internal disagreement and a fear of "ruinous" commercial development is inhibiting an honest and open discussion about the value of heritage in modern society - how it should be mediated, protected, preserved and underlying all of this: how it should be financed (Knudson, 2001; Russo, 2002; Shaw, 1992; Mason, 2008; Schwab, 2011).

In an innovative approach aimed at furthering the sustainable development of cultural resources, this paper will look into how the heritage sector can benefit from integrating elements of social entrepreneurship into its management approaches. Social entrepreneurship (SE) is an innovative approach aimed at solving the most intractable social problems we as societies face today (Wry 2006; Bornstein 2004). The protracted crisis of the heritage sector is undoubtedly to be counted amongst these. Despite this fact, the idea of applying a SE approach, as a method to develop sustainable heritage projects, is entirely innovative. This study will look into how the potential in the heritage sector can be unlocked and lead to sustainable development through a social entrepreneurially inspired management approach involving two branches of cultural heritage in cooperation - the Open-Air Museums and Heritage Crafts. These two branches are chosen as their ongoing cooperation demonstrates a key feature in SE. The use of one social problem to solve another.

Open-Air museums (OAms) have developed their particular branch of museology for nearly 150 years (Moolman 1996; Young 2006; Williams-Davies 2009). As a concept, in terms of global spread, visitor numbers and satisfaction, the OAms are highly successful, having developed an approach to 
learning which is attracting a much wider variety of visitors than conventional museums (Lyth 2006; Rentzhog 2007, pp. 371; Colomer 2002; Malcolm-Davies 2004; Zipsane 2006). Furthermore, economically, most are boasting a high degree of economic self-sufficiency (Paardekooper, 2012, pp. 107). However, despite the success of their concept many OAms are only just surviving, often forced to close over the winter months and unable to benefit from their successful approach to an extend where they can invest in long-term strategic development efforts.

On another branch within the heritage sector we have traditional crafts. Traditional crafts can be perceived as an expression of both intangible and tangible heritage. Both elements are intrinsically incorporated into the management approach of the most successful OAms, forming a very important element of both their audience and economic success. However, the vast majority of heritage crafts are struggling and several, with centuries of inherited specialist skills- are already gone (Cavalli, Comerci, \& Marchello, 2017; Heritage Crafts Association, 2017). Even if the literature agrees that crafts have great potential for economic development and job creation, in the current environment, this potential is not fulfilled (European Commission 1998; Cavalli et al. 2017; KPMG UK for the Crafts Council 2016).

These two heritage branches will, in line with latest social entrepreneurial research (Olinsson 2017), be considered as "social problems" and the cooperative development of these two branches will be reviewed for its potential to develop a sustainable and mutually beneficial cultural "product/project". For this purpose, the study will utilize the newest research/approaches in Social entrepreneurship in the form of the MSEPOT model (Olinsson 2017) in order to estimate its applicability as a management tool for developing sustainable projects in the heritage sector and how this can be developed to address or improve on, overarching institutional problems.

\subsection{Methodological approaches}

There is wide agreement that the strongest and most particular features in the success of the OAm management approach, is the active visitor participation and living history approach to learning, which is often termed "edutainment" (Bloch Ravn, 2010; Rentzhog, 2007, pp 415).

We will in the following be looking to these particular OAm approaches of active visitor participation and living history from an economic perspective. We are focusing on the use of heritage crafts in the day to day management as well as the use of specialised courses operating parallel to the daily museum management. Of particular interest is to realize what these approaches mean for the diversity of income generation and the overall economic growth potential. Can we recognise, in the cooperation between OAms and heritage crafts professionals, the potential for developing a "sustainable cultural product (SCP)" and with that an ability to formulate long-term planning and investment strategies?

In order to judge the level and success of the current experience, this study performed literature reviews of the available literature on both OAms and heritage crafts on a global scale. Specialised literature from UK and Danish crafts interests group also formed part of this review. Furthermore, for the crafts industry, a diverse range of data was collected through informal conversations with crafts practitioners encountered at different events such as fairs, festivals, workshops, crafts shops as well as at a specialised conference. Data was collected at venues in four different European countries. Further detailed studies of OAms focused on England and Denmark with interviews with management of two in-depth case studies; Weald and Downland living museum in England and Lejre; Land of Legend (A land to explore) in Denmark. The in-depth case studies represent the national strategies of England and Denmark. England, with an OAm with the most developed crafts course incorporation and Denmark, with an OAm which have just recently initiated its first forays into this particular strategy but with a very developed pedagogical strategy. These particulars make them exemplary of the scale and diversity of economic development which the OAms management 
strategy can embrace. Aimed at filling knowledge gaps in the literature, a survey for OAms in England and Denmark was designed, specifically aimed at determining how OAms see their collaboration with heritage crafts; their expectations for future collaboration and what their experience has been in term of economic and other related benefits. The questionnaire furthermore addresses the perceived distribution of benefits derived from the collaboration and if OAm recognises a "responsibility" towards the preservation of heritage crafts and how this responsibility, or lack thereof, relates to the stated aim of the OAm.

The survey was formulated as a 1-5 scaled questionnaire with 17 statements to which the museums would express their level of agreement or disagreement. All questions furthermore included the option to make further comments on the statement in question. 36\% of all OAms in Denmark and England participated with an equal division in between the countries

\section{What is Social entrepreneurship? A short introduction}

Social entrepreneurship (SE) is a relatively new concept applied to cases where long standing social problems require innovative approaches (Austin et al. 2006; Light 2008; Wry 2008). A strong sociomoral motivation is the determining aim of any SE venture (SEV) which will work with existing resources and needs rather than creating a market for new ones (Austin, Stevenson, \& Wei-Skillern, 2006; Sharir \& Lerner, 2006). As such, the innovative approaches of SE come to light through mobilizing unrecognized resources inherent in those needs (Baker \& Nelson 2005; Bornstein, 2004). At the core of $\mathrm{SE}$ is the involvement of diverse actors and partnerships through network cooperation, a strategic element which is seen as the foundation for a deeply rooted change (Stryjan 2006).

As opposed to the classical entrepreneurial approach, inherent in the SEV is a focus on sustainability. No short term goals or fast profit for a few shareholders, but rather an aim towards a lasting solution with wide benefits for stakeholders in local communities (Mair \& Martí 2006; Austin et al. 2006;

Bacq \& Janssen 2011). This focus on sustainability is what makes SEV a very promising methodological approach for cultural heritage development.

Traditionally, heritage management officers have a tendency to object against development projects as these are often being viewed a threat to heritage (Russo 2002; Knudson 2001). In meeting these concerns, the focus on sustainability is what makes SEV a very promising methodological approach for cultural heritage development.

Notwithstanding the promise of SE and the need of the heritage sector, there have till now been no studies attempting to integrate the two fields for developing a sustainable heritage management approach. As such, this study's' attempts at utilising an analytical SE tool for developing a sustainable management approach is entirely innovative.

\section{Heritage crafts}

Following our line of inquiry, in the succeeding pages we will be looking into heritage crafts to establish (i) their current situation (ii) the growth potential and the barriers for advancing heritage crafts and (iii) whether heritage crafts are a suitable partner for mutual growth in OAMs and finally (iv) how a cooperation between the two sectors can be encouraged using social entrepreneurship approaches as a sustainable growth enabler.

Heritage crafts embody knowledge and professional development going back centuries. With the rise of the industrial age however, many of these skills started to loose importance and eventually to die out. Realising the risk of imminent and permanent loss of knowledge, skills and techniques, UNESCO ratified the Convention for the Safeguarding of the intangible cultural heritage in 2003 (UNESCO 2003). Several countries worldwide have developed legal frameworks to protect heritage 
crafts, including nationally recognised titles and annual financial awards for titleholders and financially supported teaching schemes (Cavalli et al., 2017, pp. 62, 70, 72). Other supportive measures include patented quality crafts labels to products by high-quality crafts professionals (Cavalli et al., 2017; pp. 73). The protected brand of Harris Tweed in Scotland is an outstanding example of this particular quality patent which protect the process and location as well as the craftsperson (The Harris Tweed Authority n.d.). However, national efforts have been fragmented to the extent that heritage crafts face similar difficulties in countries with supportive legislation as elsewhere, leaving many heritage crafts still critically endangered (The Radcliffe Red List of endangered crafts, 2017; Cavalli et al., 2017; pp. 60; European Commission, 1998).

In a 1998 European Commission report, it is stated as fact that: "contemporary craftworks are experiencing a renaissance [...] these traditional products are able to generate an advantageous source of employment for which there is a major undeveloped potential market". It is paramount for the survival of heritage crafts to define the missing elements preventing them to connect with their potential as facilitator of economic development and job creation, for a successful revival of the crafts (Rentzhog 2007; European Commission 1998; KPMG UK for the Crafts Council 2016; Cavalli et al. 2017). Despite of these obvious and wide reaching potentials, it is a fact that crafts are at threat to their very existence. Is this a case of Schrödinger's paradox or are other issues at play?

\subsection{Specific issues affecting heritage crafts}

The issues affecting heritage crafts are highly varied and to some extend preclude general experience. In the literature ${ }_{L}$ issues are in general considered as separately and as such it is natural for them to be considered individually and as requiring separate approaches (i.e. The Radcliffe Red List of endangered crafts, 2017; Cavalli et al. 2017). In the Radcliffe Red list, the individual obstacles are listed as: lack of training opportunities, recruitment (next generation), ageing practitioners (very linked to the previous issue), loss of skill (introduction of new technologies), market (as in demand for the products), supply of raw materials, small business challenges (high costs for business locales and workshops). Other issues recognised by the literature are; lack of collaboration, lack of business and enterprise skills as well as a lack of network/platform and other associated structures (European Commission 1998; KPMG UK for the Crafts Council 2016; The Heritage Crafts Association 2018). It is worth pointing out, that the literature reflects mainly the European context and that the situation may be different outside Europe. Often the crafts professional have been unable to connect with the right type of skill or find an appropriate partner to diversify their business. Furthermore, a general lack of business skill or knowledge to correctly identify new markets or ways to change the scale or use of their product is in evidence. Additionally, traditional methods of producing and distributing are no longer adequate (Visschner 2018, personal communications; The Heritage Crafts Association 2018).

In considering the entirety of the problems facing the sector, primary amongst the needs would appear to be the establishment of a common platform- a meeting/market place - under which many of the issues facing heritage crafts could be addressed. We will return to this idea later

\section{Open-Air museums and crafts - what is the experience?}

Almost all OAMs in England have incorporated crafts courses as part of their overall museum management approach, and in quite a few instances to a very high degree. In Denmark, recent years have seen evidence of a rise of interest in this approach but as of now it is not as prevalent as in England. Comments in the recent survey (2018) indicate that limited economic availability and the perceived high costs of initiating projects of this nature, is holding some museums back. Even at Weald and Downland, which offer an impressive array of courses (4000 student days per year), 
economic limitations have so far prevented some more serious investments into the crafts coursesi.e. the purchase of potters wheels (Rowland 2016). Lejre initiated specialised courses only one year back and reported mixed success the first year, but sold out courses in the second year. Initial problems reaching the target group was deemed the reason for the initial slow upstart, with positive word-of mouth in the right circles leading to a successful second year (Holten 2018, personal communication).

Despite the perceived economic difficulties in initiating these types of initiatives, more than $66 \%$ of survey respondents, report success or great success in utilizing crafts in their particular mediation model of teaching and active visitor engagement ( 4 and 5 on a $1-5$ scale) - $20 \%$ of respondents answered neutrally (3) while $13 \%$ were leaning more towards the negative (2) (Survey 2018). On the question whether they believe crafts professionals have equally benefitted from projects with the museum, the answers are more divided in that $60 \%$ report success or great success (4-5), $13 \%$ are neutral (3) while an entire $27 \%$ believe that crafts professionals have not benefitted or only little (2). This is remarkable as cooperation between OAms and crafts professionals would seem a natural fit. How is this expressed in reality? Over a period of 18 years, the crafts programme at Weald and Downland was developed from 180 student days to 4000 student days a year and brought in approximately $20 \%$ of the yearly profits (Rowland 2016; Pailthorpe \& Purslow, 2017). To put this in perspective conventional museums in Europe in general have an own income percentage of less than 20\% (Paardekooper 2015). Despite this impressive rise in student hours, each year would see fewer local practising crafts professionals. This development is due to two factors; 1 ) Crafts professionals retire with no one to take over in their profession and 2) crafts professionals cannot make a living from their crafts and leave the profession (Rowland 2016; Heritage Crafts Association 2017). It also clearly indicate that having an OAm in the locality- even one that has integrated crafts into their mediation to a high extend, was not enough to support the local crafts. The consequence is that the museum is now often struggling with finding crafts professionals to teach their courses. Something which will be felt in their economy as popular crafts courses will disappear from their curricula (Rowland 2016).

Interestingly, there was great agreement amongst museums in the survey that they would benefit from further developing integration of crafts into their model. Again, the management of Weald and Downland concur and even though their crafts programme is the most extensive in the industry, they consider that they still have much potential for growth (Pailthorpe \& Purslow 2017).

When approached from a visitor perspective, visitor satisfaction studies conducted at Sagnlandet Lejre (2016) demonstrate that active participation is a highpoint of any visit and that visitors in general would like more opportunities to participate in these kind of activities. It is furthermore attested that extensive use of active participation as part of an immersive experience can attract age-groups which are not normally found at museums (Paardekooper, 2012, pp. 197). Visitors at Lejre demonstrate a willingness to pay a higher fee for a visit which includes more activities, but an unwillingness to pay extra for activities once on the grounds. This indicates that entrance fees could be raised if they included a choice of activities and that this option would lead to even higher satisfaction amongst visitors. Furthermore, an array of indoor activities could lead to higher visitorsatisfaction on more than one count. The Lejre satisfaction study indicates one typical complaint; weather- an OAm visit can be both wet and cold (Lejre 2016). This is of particular importance as OAms offer a largely outdoor experience and they are highly dependent on the weather with smaller and medium sized OAMs often forced to close over the winter. This is damaging for their overall reputation of reliability and for being able to keep well trained staff on the premises. Both Lejre and Weald and Downland indicate prolonged poor weather over the summer season as the single most damaging factor for their economy (Pailthorpe \& Purslow 2017; Holten 2017). 
OAms have both many issues and many objectives in common with heritage craft professionals and as concept, the idea of "crafts centres" on the museum grounds dates back to the 70s (Rentzhog 2007, pp. 397). In the survey (2018), OAms were asked whether they felt a responsibility towards preserving the build heritage as well as building crafts. For the museums who work with original buildings the answer was overwhelmingly yes, with $60 \%$ and $67 \%$ responses in the $4-5$ range respectively. On the question whether they felt a responsibility towards protecting heritage crafts in general- the answers were with an entire $80 \%$ in the positive (4-5). From the comments it can be concluded that the museums differentiate between the museums with original buildings in their care, which are perceived as having an evident responsibility towards their care and preservation, and museums with reconstructions. Amongst all the museums however, there was a strong sense of "responsibility" towards the preserving of crafts in general. Individual comments states that while in the positive this is however not their main concern. One respondent also notes that demonstrating crafts and preserving crafts are not necessarily the same, which the experience from Weald and Downland certainly demonstrates. Throughout this line of questions, there were several objections to the term "responsibility". Many OAms are operated by NGOs and have already taken great responsibilities upon themselves in attempting to save local history and heritage through preserving the buildings of their community. However, even if greater responsibilities seem beyond their means it is a relevant question whether they can continue to perform their main "responsibility" without including the care of heritage crafts in their aim.

This line of questions also features the museums responsibility to act as a resource for local community, in total almost $74 \%$ are in agreement with this statement, with $46,67 \%$ who strongly agree (5), 26,67\% who agree (4) and with only $6,67 \%$ disagreeing (2).

On the question whether OAms and their local communities would both benefit from further integrating crafts into the daily management of the museum there is still wide agreement $(73,34 \%)$. However, the numbers are reversed with $26,67 \%$ strongly agreeing (5) and $46.67 \%$ agreeing (4). This would perhaps indicate that the museums feel unsure about their ability to obtain crafts professionals from their local communities.

To recap, there is agreement amongst the museums that they benefit by integrating crafts into their daily management. They are however, limited by their economic situation which is too weak to encourage significant investments for future development. The museums are keen to point out that these benefits are both economic and pedagogical and work intrinsically with their active visitor approach. The surveyed museums do in general feel a "responsibility" towards preserving heritage crafts but do not feel that is it necessarily part of their main aim. Museums furthermore question whether utilising crafts in museum demonstrations alone can achieve a goal of heritage crafts preservation. And although the grand majority judge that the crafts profession has benefitted from cooperation with the museums, many have observed only limited benefits for the crafts professionals. The experience from Weald and Downland who are noticing a fall in the number of local crafts professionals despite their rather developed crafts programme might indicate that another level of cooperation entirely is necessary.

Below, the modified Problem and Objective tree will be assessed to explore the suitability of this tool of solving the problems inherent in their cooperation and in a heritage context. 


\section{Applying the mSEPOT}

mSEPOT ${ }^{1}$ stands for; modified Social Entrepreneurial Problem and Objective Tree (Olinsson 2017). The original Problem and Objective Tree is a participatory analysis tool central to project planning (Figure 1). As an analytical tool the Problem Tree is used to map out situational problems along lines of causes, effects and their interrelations as they relate to one central problem.

The model is divided in three parts named after the parts of a tree: roots, trunk and branches. The roots hold the causes, the trunk the main problem and the branches the effects. Once the problems are mapped out in the problem tree, the Objective Tree is utilized to identify clear and manageable goals and the strategy of how to achieve them.

The process going from problem tree to objective tree lies in turning individual elements into their own objectives. As an example, the causal problem of: "too few women working in the field" is as a direct objective turned into: "more women are working in the field". This element will work towards solving the main problem/objective as it is revealed in the model which objectives should be targeted for most effect.

Olinsson (2017) devised a modified version of the Problem and Objective Tree aimed at use in planning SE projects. The main modification pertained to the realisation that a SE project per definition deals with two

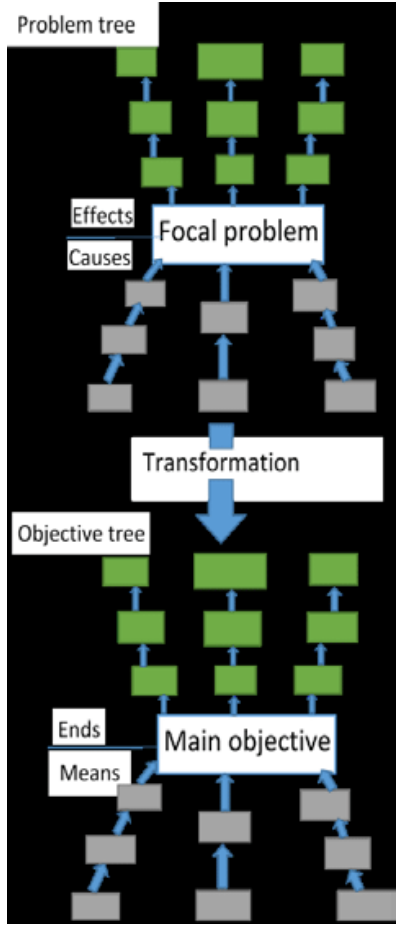

Figure 1. Original Problem and Objective Tree main problems instead of one and uses one of the problems as a resource in order to solve the other. One of these problems will be linked to the causal problems while the other problem will be linked to the effects. This was found to be fundamental to SE thinking.

As per guidance for the MSEPOT model, two principal and interdependent problems, which the model will attempt to address, are identified. These are positioned in the "trunk" of the tree. Apart from these main problems, the study demonstrated that the relevant data required for the use of the mSEPOT are social problems (Olinsson 2017). As heritage is a social "good", problems affecting the sustainability and wellbeing of this field are considered social problems. For this study, the "problem data" used in the model concerns issues relating directly to the current cooperation between the two fields of OAms and heritage crafts. The relevant data regarding their current situation and their cooperation, has been gathered through literature reviews, special reports, interviews, informal conversations, conference participation, and focused survey and visitor studies allowing the author to perform the role of "stakeholder network" and testing of the MSEPOT when applied to a real world case.

Olinsson (2017) furthermore established that in order to utilize the MSEPOT for its intended purpose and achieve the inherent sustainability of a SEV, it must function within a wider SEV framework which has 5 requirement;

1) Socio-moral objective of the social entrepreneur.

2) Aspects and importance of network.

3) Resources

${ }^{1}$ For the full introduction into the workings of this model see: Olinsson (2017), Social Entrepreneurship-Committing Theory to Practice. Journal of Social Entrepreneurship, Volume 8 (2). 


\section{4) Innovation \\ 5) Organisational construct.}

1) The SEV has an imbedded socio-moral objective. The preservation of cultural heritage for the benefit of humanity is considered as such. 2) Any functioning SEV will be developed through a network approach. This gives the venture the benefit of a deep understanding of potentials as well as issues and underpins an equal partnership. 3) In accordance with SE thinking, the knowledge inherent in the struggling crafts is "re-imagined" as a resource for its potential as a SCP. Essentially, the product being developed is an actual part if the issue being analysed. The definition of a SCP is: $a$ marketable product, based on intangible heritage, which does not cause damage to the heritage fabric even though it is based on, and markets, heritage. Where all museum artefacts deteriorate with use, both the knowledge and the actual production of the crafts are sustainable, plus, rather than being detrimental to the preservation, the continued use of heritage crafts is important to sustain and preserve valuable knowledge. 4) The teaching and developing of the intangible heritage inherent in crafts as a "sustainable cultural product" is considered an innovative approach. 5) All parties will participate in funding the continued development through re-investment in the cooperation. This is a key feature for the sustainability of the venture and an important reason why the SE approach is considered very relevant for heritage management. 


\subsection{Developing a heritage SEV using the MSEPOT}

The question this paper set out to explore was; can a cooperation between these two fields, using management approaches from social entrepreneurship, unlock their potential and encourage a sustainable outcome? If this tool is suitable, the second stage of the MSEPOT should give us a clear picture regarding where and how their cooperation can be improved. In preparation to the use of the model, the user (network of stakeholders) will list all the problems which they find are related to their principal problems. Once the list is exhaustive, the problems will be divided in causes or effects (Table 1). In SE there are always more causes than effects. Once this initial division is in place, causes and effects will be positioned according to their importance and role. As such the most fundamental cause is positioned furthest towards the lowest reach of the roots. This is a cause affecting everything above. The other causes will be positioned along the roots, mapping out their position to the other causes and arrows between them will indicate in which way and what other causes are effected by them. It is a particular of SE projects that both causes and effects are highly interconnected. Above the principal problems, the same analytical mapping of effects is laid out. As with the actual division of causes and effects, the weight and position of each element is given by the users of the model and as such can vary. It is always subjective which is a cause and which an effect is and a different network might perceive slightly different configurations. However, as this is an analysis of a real life situation, and networks should be made up of knowledgeable stakeholders analysing real life issues pertaining to their own situation, variations should be slight and not affect the overall analysis.

\section{Initiating the mSEPOT analysis}

The two principal problems which this study will focus on are:

Crafts are dying out and OAms are struggling with poor economy.

\begin{tabular}{|l|l|}
\hline Causes & Effects \\
\hline Crafts are unorganised & Too few crafts professionals (OAm) \\
\hline Lacking business skills (OAms/Crafts) & $\begin{array}{l}\text { Cannot stock quality products (economy) } \\
\text { (OAms) }\end{array}$ \\
\hline Too high costs (Crafts/OAms) & $\begin{array}{l}\text { The museums cannot invest in development } \\
\text { projects }\end{array}$ \\
\hline $\begin{array}{l}\text { Too few venues for spreading knowledge on } \\
\text { crafts selling/teaching }\end{array}$ & Are forced to close over winter (OAm) \\
\hline No organised teaching of crafts & $\begin{array}{l}\text { Museums will struggle to attract and keep best } \\
\text { qualified people }\end{array}$ \\
\hline $\begin{array}{l}\text { Crafts professional are isolated- lack business } \\
\text { partners/students }\end{array}$ & \\
\hline $\begin{array}{l}\text { It is difficult to live off crafts } \\
\text { Cannot market/use products effectively } \\
\text { (Crafts/OAm) }\end{array}$ & \\
\hline
\end{tabular}




\section{MSEPOT}

\section{First stage: Problem Tree}

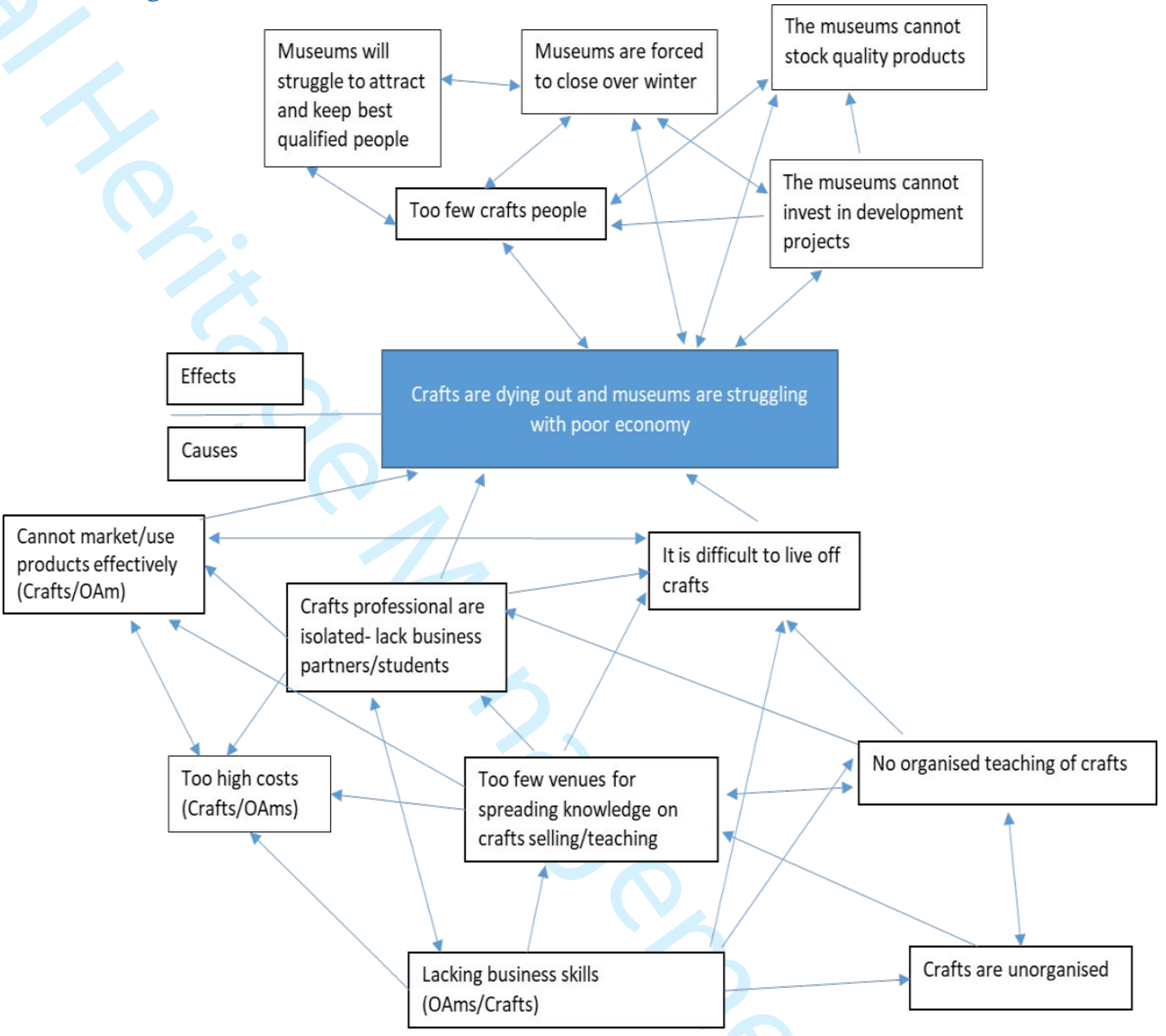

Figure 2. The ISEPOT; Problem Tree 
Figure 3. The mSEPOT; Objective Tree.

\section{Stage 2: Objective Tree}

The conversion of this particular "issue" in "means" suggests us to: Develop bigger venues to increase knowledge amongst buyers, students and other crafts professionals as well as utilize the space for selling products and teaching.

In the first Problem tree stage, this issue was acting as direct cause on 6 out of 8 related causal elements, as a means element, in the second stage, this has been augmented to 7 out of 8 demonstrating its unquestionable central role in the causative means chain.

The two principal problems are transformed into our main objective by utilising the mSEPOT approach of transforming one problem into a resource able to solve the other problem. In the 
MSEPOT the cause related problem is viewed for its ability to act as a resource to address the effect related problem. As can clearly be seen in the model, the causal side of the chain is significantly connected to crafts related issues, while the effects are more clearly seen on the museum part. Hence the resource should be found in the crafts side of the focal problems.

The conversion is not an unquestionable opposite transformation of the principal problems, rather in their transformation they are informed and influenced by the suggestions of the means chain. As such our informed main objective reads as follows:

Through integrating crafts- the museum economy is improved. And our Objective tree model suggests this should be done by: Developing bigger venues to increase knowledge amongst buyers, students and other crafts professionals as well as utilize the space for selling products and teaching

\section{Market place}

In the following we will look into how OAms could form such a venue and how the concept should be developed to reap the full potential and benefit both parties as equal partners in line with SE approaches to sustainable development.

The best solutions are often the simplest ones. The European Commission report of 1998 looked at the problems of heritage crafts disappearing and concludes that the best option for taking advantage of the underdeveloped potential inherent in heritage crafts would be to create strong networks between main players and setting up "selling sites" which could act as a "platform for cultural, scientific, educational and economic exchange". More recently and along the same lines, a UK Crafts Council report suggests to create a system of "art profession centres" to supports craft professionals and job creation (KPMG UK for the Crafts Council 2016).

Very similar ideas have been in circulation in OAm circuits since the 1970s when Avoncraft OAm proposed the establishment of "advice centres" for the preservation of buildings (Rentzhog 2007, pp. 397). Speaking from the point of view of OAms, Rentzhog (2007, pp. 398) sees a cooperation between crafts professionals and OAms as potentially very beneficial. Rentzhog perceives OAms as a natural platform and the cooperation as a natural extension of the building preservation aim which many OAms already hold. He concludes that such a cooperation would make good use of OAms competences and have many layered benefits for OAms and crafts- in particular building crafts which are seen as particularly in tune with the stated aim of many OAms.

\subsection{An OAm- heritage crafts cooperative}

In contemplating the potential nature of a market place collaboration between OAMs and crafts professionals, the practices of cooperatives come to mind. The definition of a cooperative is an organisation which is owned and run jointly by its members who share the costs, benefits and profits. Together, owners can create improved benefits and development opportunities through approaches that would be impossible for the individual business owner but which become possible for the venture. As such, cooperatives have existed as a solution for the problems facing small scale businesses for centuries. These problems are common for both heritage craft professionals and OAms and the joining of forces, both in between crafts professionals and museums, as well as amongst crafts professionals/museums themselves could have very positive outcomes (Rentzhog 20017, pp. 463). As seen above, on their own, OAms struggle to afford developing or even initiating crafts courses. Also, museum shops, cafés and restaurants are an important but underdeveloped potential which many museums are unable to establish on their site (Paardekooper, 2012, pp. 260; Holten, 2017). Sadly, even museums with established restaurants and shops are struggling with 
supplying (artisanal) high quality products suitable for their particular museum audience. Again, this is an issue facing Small scale businesses; many museums on their own do not have the necessary funds to buy the minimum stocks required by sellers or hire crafts professionals to produce products for sale (Holten 2017; Paardekooper, 2012, pp. 260; Rentzhog 2007, pp. 463). In many aspects of practical cooperation such as common training, marketing and lobbying efforts, joint development projects and material, OAMs have a lot to gain from joining forces.

In the case of heritage crafts, the cooperative set-up can help solve many of the problems faced by the profession. Starting from a physical perspective, a "cooperative" communal space can lessen the economic burden of individual crafts professionals through functioning as a joint workshop and shop space and even making material expenses more affordable as the cooperative will be able to put in bigger orders. From a non-physical perspective, a joint organisation whether based around the shared physical space or the organisation as a whole, can solve issues of isolationism and allow skills and inspirational exchange and training. It will furthermore limit marketing expenses allowing for a concerted marketing effort connecting crafts professionals with both potential customers, students and relevant partners. Adding extra value, a setup within the confines of the OAm serve to broaden the width of potential customers at the shop door as well as the scope of what part of the crafts product you sell- the knowledge or the finished product.

\section{Conclusion}

The overarching purpose of this study was to identify the specific growth potentials of an OAm and crafts cooperation by using SE approaches as a sustainable growth enabler. Key elements were the establishment of the concept of a "SCP" inherent in the OAm approach, as well as its role as a fundamental element in a sustainable cultural project. The fundamental OAm management approach, relying chiefly on active visitor engagement and living history, offers a potentially never ending prospect of varied active learning. The approach has strong roots in the OAm community but current implementations have failed to reach full potential and is falling short of sustainability goals. As we have seen, the MSEPOT tool suggests developing venues for crafts on the museum premises as a means to address the intractable problems that plague both fields and a way to improve their cooperation. However, while superficially the MSEPOT suggestion does appear to closely match both the suggestions made in the literature and actual approaches at OAMs, in reality the MSEPOT model goes much deeper, closely reviewing the problems of the current cooperation and suggesting an updated approach which holds a deciding element towards a SE conversion .

In accordance with the basic framework of the MSEPOT, one integral element of a SEV, which presently is not in effect, is the network cooperation. Currently, cooperation between OAm and crafts professionals is heavily skewered towards benefitting the OAm who, as the organizer, decides the aim of the cooperation. The survey demonstrated that most OAms fail to realise the fundamental importance of heritage crafts on their visitor and management approach and hence to anticipate the disastrous effect of a disappearing heritage crafts profession on their own livelihoods. Within a SEV network cooperation, the current aim would be comprehensively extended to include the protection and preservation of heritage crafts. The network, with its equal partnership, would ensure the development of a market place with equal benefits. This approach sets both aim and outcome apart from the current cooperation. The SE aspect of reinvesting into the venture as a fundamental aspect of the organizational construct of a SE is also not in effect. A relevant example comes from Weald and Downland, where Rowland (2016) noted that the crafts programme did not have the necessary funds to invest in furthering the scheme as income was being diverted to other areas of the museum management. 
This is an exploratory study, and for the purposes of the study, the author has performed the integral role of "network" by collecting a wide array of pertinent "data" allowing for the initial use of the MSEPOT. This approach is believed to have developed credible results but does have weaknesses compared to a true network, which would be exchanging and building knowledge organically. Even given this weakness, the results suggest that the tool could have an important supporting role to help introduce SE approaches into the heritage management field. Given the enormous problems which threaten our cultural heritage and given the longevity of these problems, new approaches to support a sustainable development of heritage resources are needed. Unfortunately, negative examples of "ruinous" commercial developments abound, making heritage managers sceptical at cultural development schemes initiated from beyond the field. As such, the MSEPOT offers a field, which is not naturally prone to entrepreneurial initiatives, the tool needed to lead an advance of the field in a sustainable manner. For the next step, real-world attempts at utilizing the tool are needed to validate and further develop this method.

\section{Bibliography}

Austin, J., Stevenson, H. \& Wei-Skillern, J., 2006. Social and Commercial Entrepreneurship: Same, Different, or Both? Entrepreneurship Theory and Practice, 30(1), pp.1-22.

Bacq, S. \& Janssen, F., 2011. The multiple faces of social entrepreneurship: A review of definitional issues based on geographical and thematic criteria. Entrepreneurship \& Regional Development, 23(5-6), pp.373-403.

Bloch Ravn, T., 2010. Updating den Gamle By. Acta Ethnographica Hungarica, 55(2), pp.313-332.

Bornstein, D., 2004. How to change the world: social entrepreneurs and the power of new ideas, Oxford publications. Oxford.

Cavalli, A., Comerci, G. \& Marchello, G., 2017. Masters touch: essential elements of artisanal excellence, Marsilio. Venice.

Colomer, L., 2002. Educational facilities in archaeological reconstructions. Public archaeology, 2.

European Commission, 1998. Promoting creation and development of sustainable employment in the rare crafts sector., Luxenborg.

Heritage Crafts Association, 2017. The Radcliffe Red List of endangered crafts, Edale.

Holten, L., 2017. Director of Lejre- Land of Legend Open-Air museum. Personal interview.

Knudson, R., 2001. Cultural Resource Management in Context. Archives and Museum Informatics, 13(3-4), pp.359-381.

KPMG UK for the Crafts Council, 2016. Innovation through craft: Opportunities for growth; A report for the Crafts Council, Crafts Council, London

Loulanski, T., 2007. Revising the Concept for Cultural Heritage: The Argument for a Functional Approach. International Journal of Cultural Property, 13(02), pp.207-233.

Lyth, P., 2006. Selling history in an age of industrial decline: heritage tourism in Robin Hood county. In XIV International Economic History Congress. Helsinki, pp. 1-17.

MacDonald, G.F.G. \& Alsford, S., 1995. Museums and theme parks: Worlds in collision? Museum Management and Curatorship, 14(2), pp.129-147.

Mair, J. \& Martí, I., 2006. Social entrepreneurship research: A source of explanation, prediction, and delight. Journal of World Business, 41(1), pp.36-44. 
Malcolm-Davies, J., 2004. Borrowed Robes: The Educational Value of Costumed Interpretation at Historic Sites. International Journal of Heritage Studies, 10(3), pp.277-293.

Mason, R., 2008. Be Interested and Beware: Joining Economic Valuation and Heritage Conservation. International Journal of Heritage Studies, 14(4), pp.303-318.

Mason, R., 2005. Economics and Historic Preservation: a guide and review for litterature, The Brookings Institution, Washington DC.

Matero, F., Fong, K. \& Bono, E. Del, 2013. Archaeological site conservation and management An appraisal of recent trends. and management of archaeological sites.

Moolman, H., 1996. Site museums: Their origins, definition and categorisation. Museum Management and Curatorship.

Olinsson, S.B., 2017. Social Entrepreneurship-Committing Theory to Practice. Journal of Social Entrepreneurship, 8(2), pp.225-247.

Paardekooper, R., 2012. The value of an archaeological open-air museum is in its use, Sidestone Press. Leiden.

Pailthorpe, R. \& Purslow, M., 2017. Foremer Director and CEO of Weald and Downland Living museum. Personal interview.

Rentzhog, S., 2007. Open air museums. The history and future of a visionary idea, Jamtli Förlag and Carlsson Bokförlag. Kristianstad.

Ross, M., 2004. Interpreting the new museology. Museum and society, 2(2), pp. 84-104.

Rowland, D., 2016. Head of learning at Weald and Downland Living museum. Personal interview.

Russo, A.P., 2002. The "vicious circle" of tourism development in heritage cities. Annals of Tourism Research, 29(1), pp.165-182.

Schwab, N., 2011. Increasing Europe's Competitiveness Through Cultural Heritage Research: An Initiative of the EU Project NET-HERITAGE, 24 March 2011. International Journal of Cultural Property, 18(04), pp.443-447.

Sharir, M. \& Lerner, M., 2006. Gauging the success of social ventures initiated by individual social entrepreneurs. Journal of World Business, 41(1), pp.6-20.

Shaw, G., 1992. Culture and Tourism: The economics of Nostalgia. World Futures, 33(1-3), pp.199212.

Stryjan, Y., 2006. The practice of Social entrepreneurship: Notes towards a resource-perspective. In C. Steyaert \& D. Hjorth, eds. Entrepreneurship as social change. Elgar. Cheltenham, p. 327.

The Harris Tweed Authority, www.harristweed.org.

The Heritage Crafts Association, 2018. Crafts for the Future conference. London.

UNESCO, 2003. Convention for the Safeguarding of the Intangible Cultural Heritage, https://ich.unesco.org/doc/src/15164-EN.pdf.

Visschner, W., 2018. E-mail conversation.

Williams-Davies, J., 2009. "Now Our History is Your History": The Challenge of Relevance for OpenAir Museums. Folk Life.

Wry, T. 2008. An Integrative Framework to Understand Social Entrepreneurship. Paper presented at 
the 2nd International Social Entrepreneurship Research Conference, New York, NY

Young, L., 2006. Villages that Never Were: The Museum Village as a Heritage Genre. International Journal of Heritage Studies, 12(4), pp.321-338.

Zipsane, H., 2006. Lifelong Learning in Open Air Museums - A fascinating part to play in Europe. pp.1-7. Paper presented at the 22nd Conference of the European Association of Open Air Museums in Finland, Åbo. 
Figures for: Social entrepreneurship for sustainable heritage management - The case of Open-Air museums

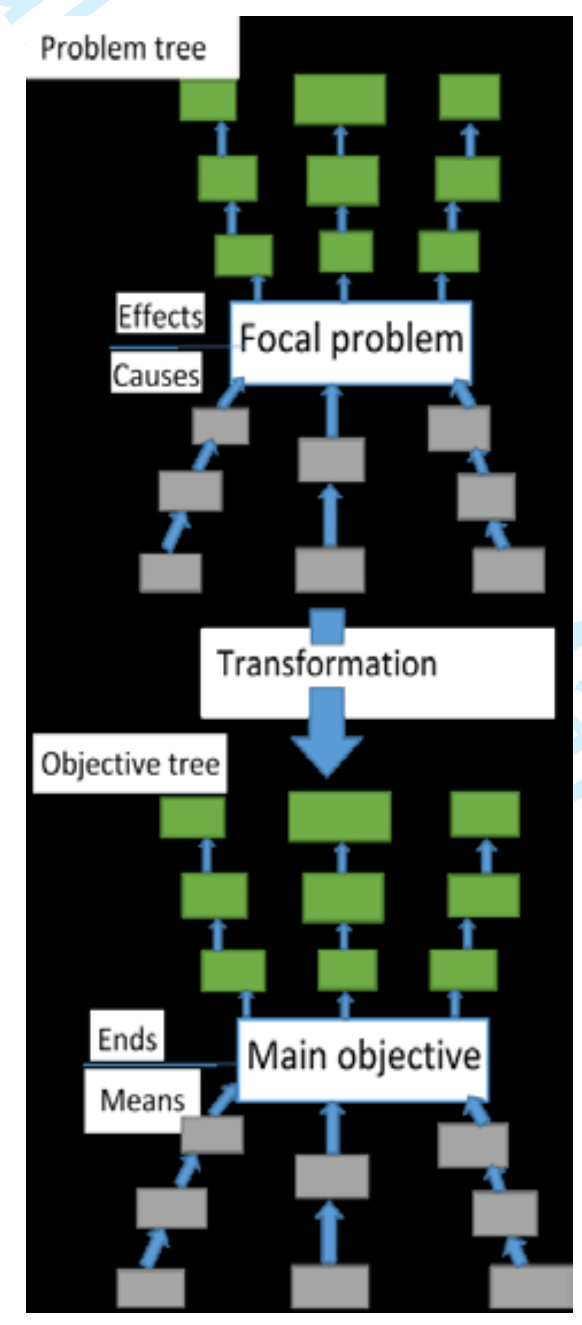

Figure 1. Original Problem and Objective Tree 


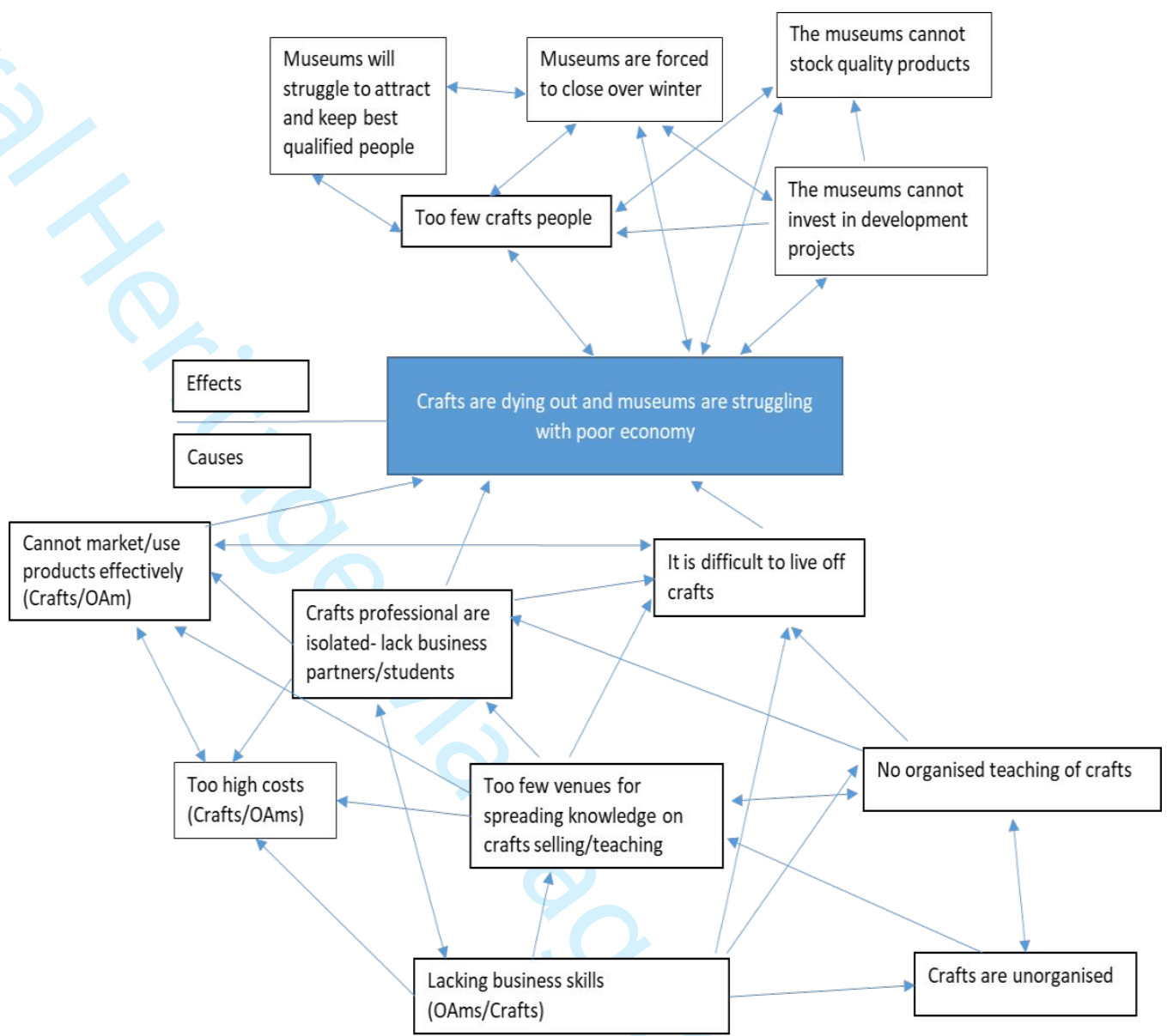

Figure 2. The mSEPOT; Problem Tree 
Crafts are dying out and OAms are struggling with poor economy.

\begin{tabular}{|l|l|}
\hline Causes & Effects \\
\hline Crafts are unorganised & Too few crafts professionals (OAm) \\
\hline Lacking business skills (OAms/Crafts) & $\begin{array}{l}\text { Cannot stock quality products (economy) } \\
\text { (OAms) }\end{array}$ \\
\hline Too high costs (Crafts/OAms) & $\begin{array}{l}\text { The museums cannot invest in development } \\
\text { projects }\end{array}$ \\
\hline $\begin{array}{l}\text { Too few venues for spreading knowledge on } \\
\text { crafts selling/teaching }\end{array}$ & Are forced to close over winter (OAm) \\
\hline $\begin{array}{l}\text { No organised teaching of crafts } \\
\text { prafts professional are isolated- lack business } \\
\text { partnerstudents }\end{array}$ & $\begin{array}{l}\text { Museums will struggle to attract and keep best } \\
\text { qualified people }\end{array}$ \\
\hline $\begin{array}{l}\text { It is difficult to live off crafts } \\
\text { (Crafts/OAm) }\end{array}$ & \\
\hline
\end{tabular}

Table 1. Causes and effects surrounding the two principal problems of the cooperation 


\section{Summary report}

Lists all the questions in the survey and displays a summary with chart for each question. Free text responses are not included.

\section{Table of contents}

Report info... 1

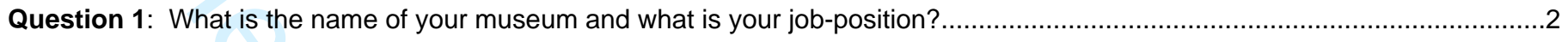

Question 2: Open-air museums operate differently from conventional museums...................................................................

Question 3: Active participation from the visitor is important at Open-Air museums............................................................

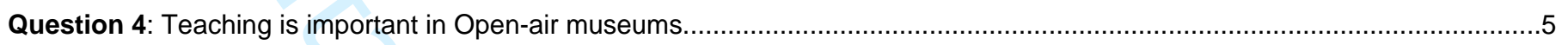

Question 5: Open-air museums are more open to new approaches than conventional museums..............................................6

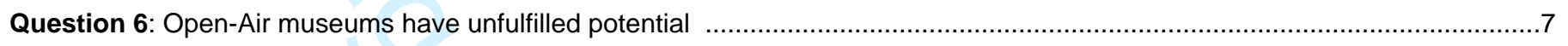

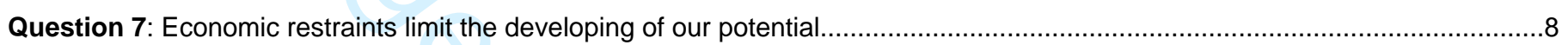

Question 8: What do you consider the strongest feature of the open-air museums concept? ................................................

Question 9: Open-air museums have a responsibility towards preserving the build heritage...................................................10

Question 10: Open-air museums have a responsibility towards preserving building crafts

Question 11: Open-air museums have a responsibility towards preserving crafts...................................................................12

Question 12: Open-air museums have a responsibility to act as a resource for their local community.....................................13

Question 13: My museum has had success with integrating crafts into the mediation model. With mediati.................................14

Question 14: Crafts and craft professionals have benefited from projects with my museums.................................................15

Question 15: Open-air museums could benefit from further developing integration of crafts into their .....................................16

Question 16: Open-air museums could benefit from further developing their active visitor approach........................................17

Question 17: Open-air museums and their local community could benefit from further developing the int.................................18

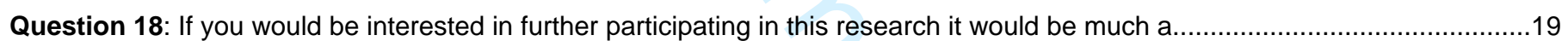




\section{Report info}

\section{Report date:}

Start date:

Stop date:

Stored responses:

Number of completed responses:

Number of invitees:

Invitees that responded:

Invitee response rate:
Wednesday, February 6, 2019 1:58:58 PM GMT

Monday, January 15, 2018 11:05:00 AM GMT

Thursday, May 31, 2018 11:05:00 AM BST

18

15

43

6

$13.95 \%$ 


\section{Question 1}

What is the name of your museum and what is your job-position? 


\section{Question 2}

Open-air museums operate differently from conventional museums

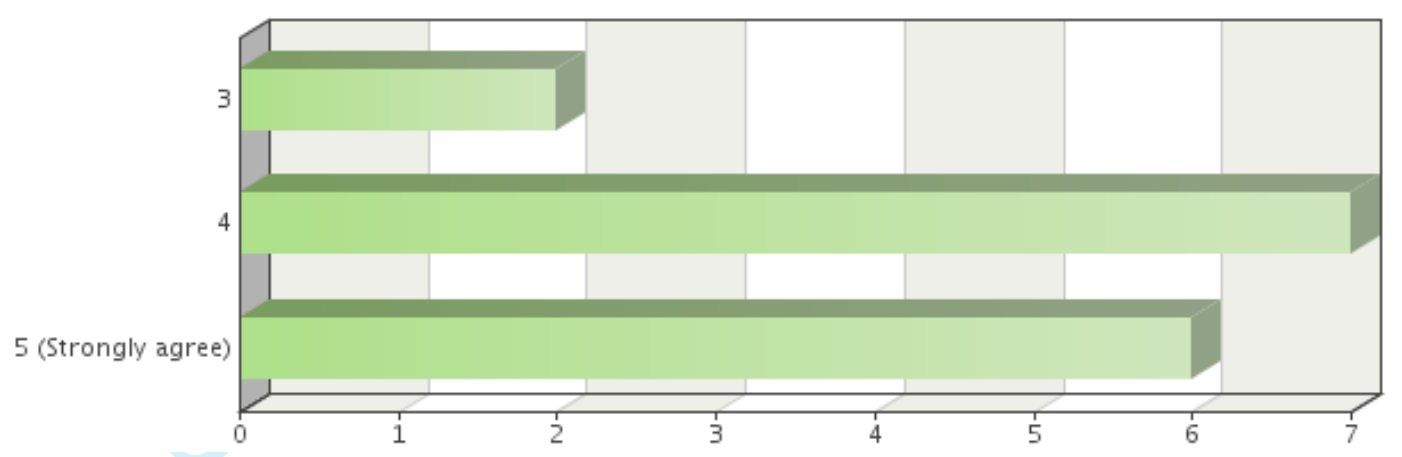

Frequency table

\begin{tabular}{|c|c|c|c|}
\hline Levels & $\begin{array}{l}\text { Absolute } \\
\text { frequency }\end{array}$ & $\begin{array}{l}\text { Relative } \\
\text { frequency }\end{array}$ & $\begin{array}{l}\text { Adjusted } \\
\text { relative } \\
\text { frequency }\end{array}$ \\
\hline 3 & 2 & $11.11 \%$ & $13.33 \%$ \\
\hline 4 & 7 & $38.89 \%$ & $46.67 \%$ \\
\hline 5 (Strongly agree) & 6 & $33.33 \%$ & $40 \%$ \\
\hline Sum: & 15 & $83.33 \%$ & $100 \%$ \\
\hline Not answered: & 3 & $16.67 \%$ & - \\
\hline
\end{tabular}




\section{Question 3}

Active participation from the visitor is important at Open-Air museums

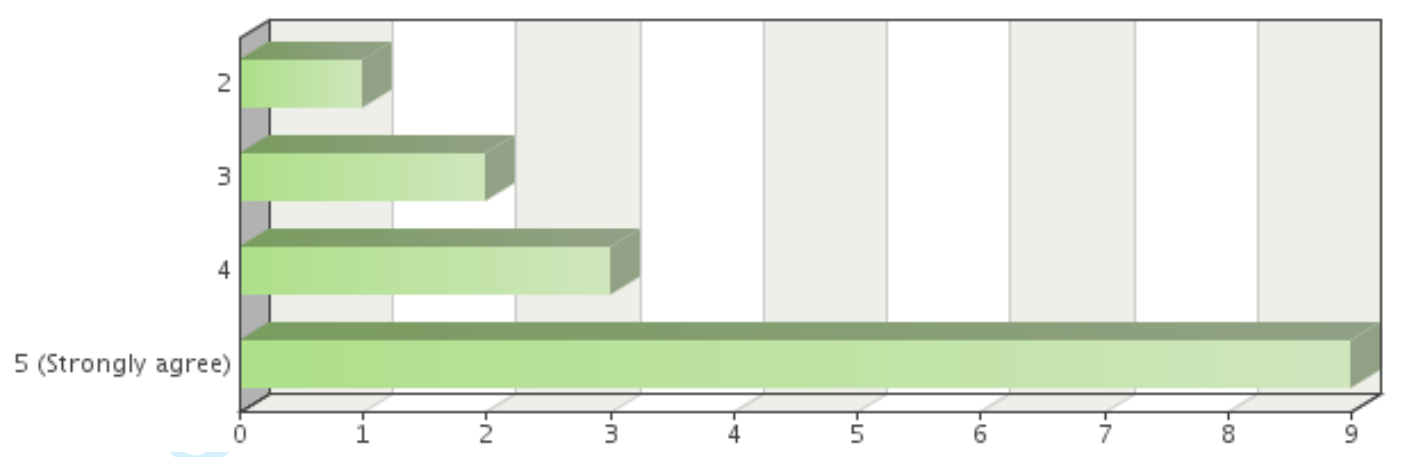

Frequency table

\begin{tabular}{|c|c|c|c|}
\hline Levels & $\begin{array}{l}\text { Absolute } \\
\text { frequency }\end{array}$ & $\begin{array}{l}\text { Relative } \\
\text { frequency }\end{array}$ & $\begin{array}{l}\text { Adjusted } \\
\text { relative } \\
\text { frequency }\end{array}$ \\
\hline 2 & 1 & $5.56 \%$ & $6.67 \%$ \\
\hline 3 & 2 & $11.11 \%$ & $13.33 \%$ \\
\hline 4 & 3 & $16.67 \%$ & $20 \%$ \\
\hline 5 (Strongly agree) & 9 & $50 \%$ & $60 \%$ \\
\hline Sum: & 15 & $83.33 \%$ & $100 \%$ \\
\hline Not answered: & 3 & $16.67 \%$ & - \\
\hline
\end{tabular}




\section{Question 4}

Teaching is important in Open-air museums

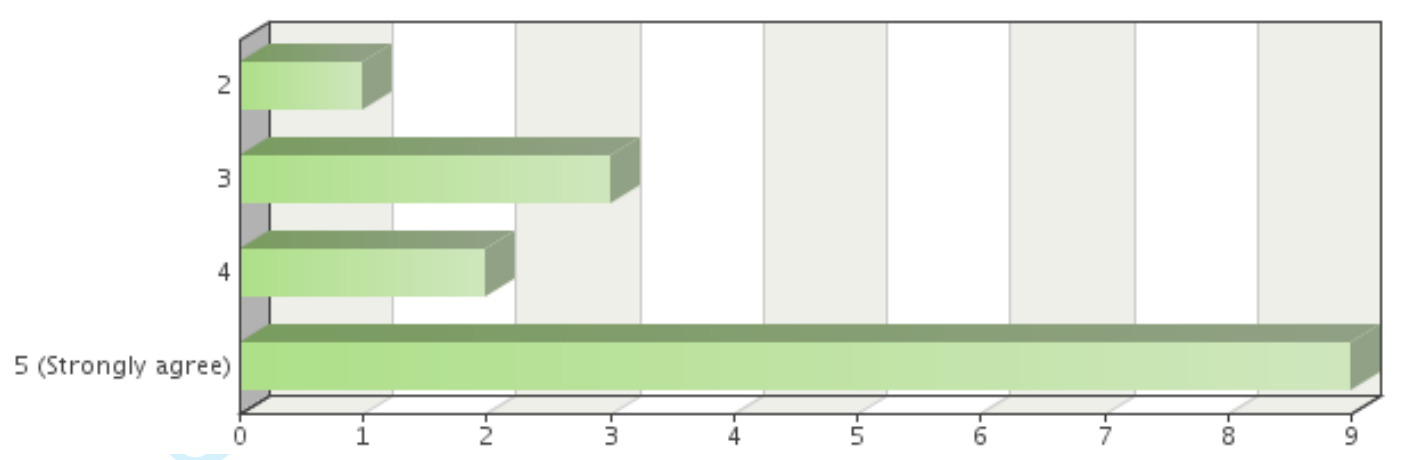

Frequency table

\begin{tabular}{llll}
\hline Levels & $\begin{array}{l}\text { Absolute } \\
\text { frequency }\end{array}$ & $\begin{array}{l}\text { Relative } \\
\text { frequency }\end{array}$ & $\begin{array}{c}\text { Adjusted } \\
\text { relative } \\
\text { frequency }\end{array}$ \\
\hline 2 & 1 & $5.56 \%$ & $6.67 \%$ \\
3 & 3 & $16.67 \%$ & $20 \%$ \\
4 & 2 & $11.11 \%$ & $13.33 \%$ \\
5 (Strongly agree) & 9 & $50 \%$ & $60 \%$ \\
\hline Sum: & 15 & $83.33 \%$ & $100 \%$ \\
\hline Not answered: & 3 & $16.67 \%$ & - \\
\hline
\end{tabular}




\section{Question 5}

Open-air museums are more open to new approaches than conventional museums

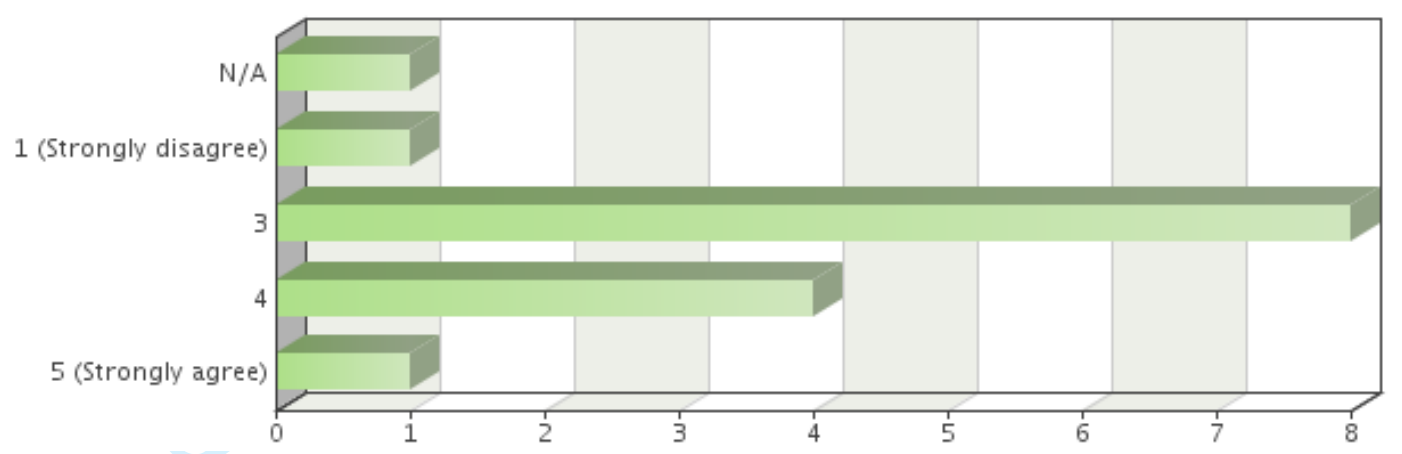

Frequency table

\begin{tabular}{|c|c|c|c|}
\hline Levels & $\begin{array}{l}\text { Absolute } \\
\text { frequency }\end{array}$ & $\begin{array}{l}\text { Relative } \\
\text { frequency }\end{array}$ & $\begin{array}{l}\text { Adjusted } \\
\text { relative } \\
\text { frequency }\end{array}$ \\
\hline $\mathrm{N} / \mathrm{A}$ & 1 & $5.56 \%$ & $6.67 \%$ \\
\hline 1 (Strongly disagree) & 1 & $5.56 \%$ & $6.67 \%$ \\
\hline 3 & 8 & $44.44 \%$ & $53.33 \%$ \\
\hline 4 & 4 & $22.22 \%$ & $26.67 \%$ \\
\hline 5 (Strongly agree) & 1 & $5.56 \%$ & $6.67 \%$ \\
\hline Sum: & 15 & $83.33 \%$ & $100 \%$ \\
\hline Not answered: & 3 & $16.67 \%$ & - \\
\hline
\end{tabular}




\section{Question 6}

\section{Open-Air museums have unfulfilled potential}

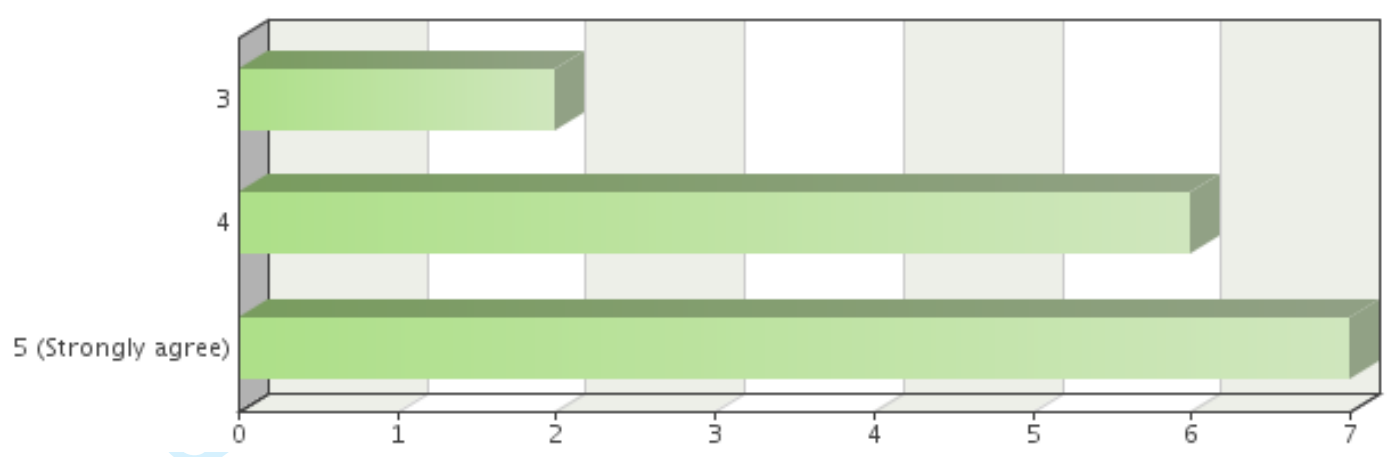

Frequency table

\begin{tabular}{|c|c|c|c|}
\hline Levels & $\begin{array}{l}\text { Absolute } \\
\text { frequency }\end{array}$ & $\begin{array}{l}\text { Relative } \\
\text { frequency }\end{array}$ & $\begin{array}{l}\text { Adjusted } \\
\text { relative } \\
\text { frequency }\end{array}$ \\
\hline 3 & 2 & $11.11 \%$ & $13.33 \%$ \\
\hline 4 & 6 & $33.33 \%$ & $40 \%$ \\
\hline 5 (Strongly agree) & 7 & $38.89 \%$ & $46.67 \%$ \\
\hline Sum: & 15 & $83.33 \%$ & $100 \%$ \\
\hline Not answered: & 3 & $16.67 \%$ & - \\
\hline
\end{tabular}




\section{Question 7}

Economic restraints limit the developing of our potential

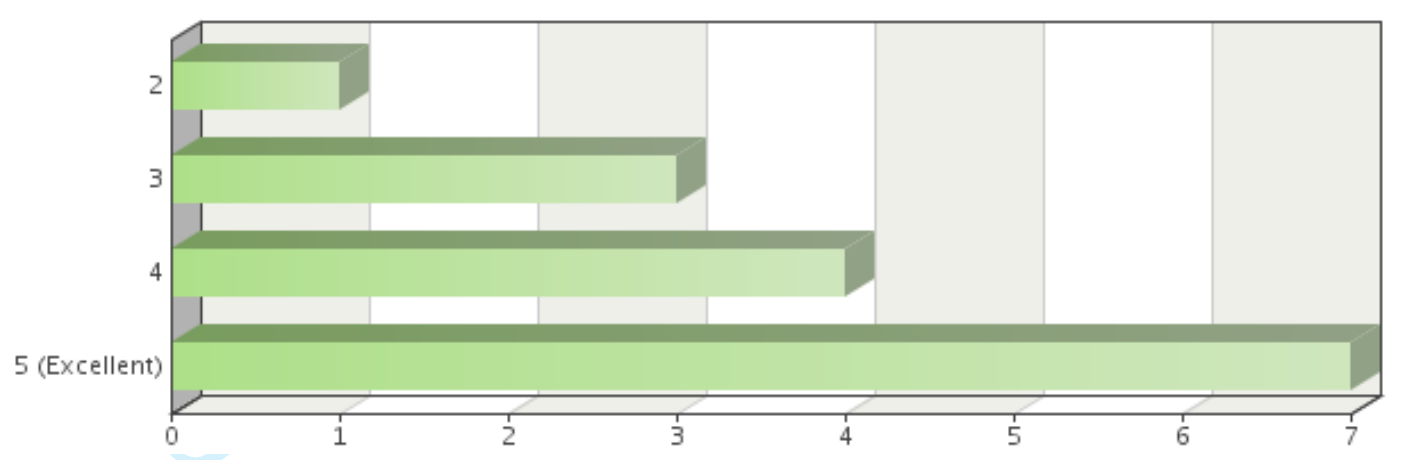

Frequency table

\begin{tabular}{|c|c|c|c|}
\hline Levels & $\begin{array}{l}\text { Absolute } \\
\text { frequency }\end{array}$ & $\begin{array}{l}\text { Relative } \\
\text { frequency }\end{array}$ & $\begin{array}{l}\text { Adjusted } \\
\text { relative } \\
\text { frequency }\end{array}$ \\
\hline 2 & 1 & $5.56 \%$ & $6.67 \%$ \\
\hline 3 & 3 & $16.67 \%$ & $20 \%$ \\
\hline 4 & 4 & $22.22 \%$ & $26.67 \%$ \\
\hline 5 (Excellent) & 7 & $38.89 \%$ & $46.67 \%$ \\
\hline Sum: & 15 & $83.33 \%$ & $100 \%$ \\
\hline Not answered: & 3 & $16.67 \%$ & - \\
\hline
\end{tabular}




\section{Question 8}

What do you consider the strongest feature of the open-air museums concept?

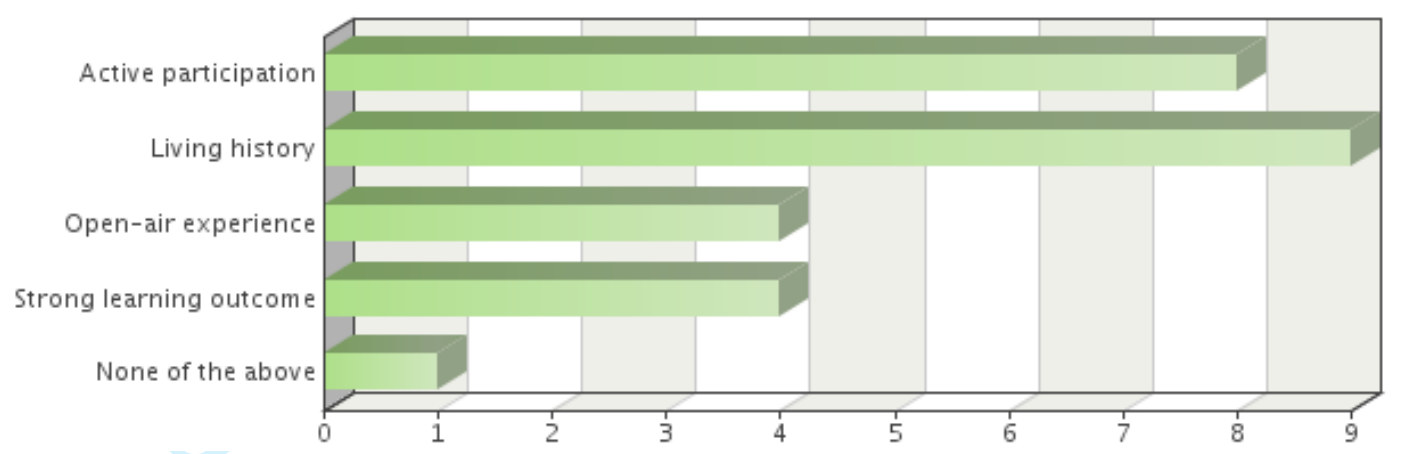

Frequency table

\begin{tabular}{|c|c|c|c|c|}
\hline Choices & $\begin{array}{l}\text { Absolute } \\
\text { frequency }\end{array}$ & $\begin{array}{l}\text { Relative } \\
\text { frequency } \\
\text { by choice }\end{array}$ & $\begin{array}{l}\text { Relative } \\
\text { frequency }\end{array}$ & $\begin{array}{l}\text { Adjusted } \\
\text { relative } \\
\text { frequency }\end{array}$ \\
\hline Active participation & 8 & $30.77 \%$ & $44.44 \%$ & $53.33 \%$ \\
\hline Living history & 9 & $34.62 \%$ & $50 \%$ & $60 \%$ \\
\hline Open-air experience & 4 & $15.38 \%$ & $22.22 \%$ & $26.67 \%$ \\
\hline Strong learning outcome & 4 & $15.38 \%$ & $22.22 \%$ & $26.67 \%$ \\
\hline None of the above & 1 & $3.85 \%$ & $5.56 \%$ & $6.67 \%$ \\
\hline Sum: & 26 & $100 \%$ & - & - \\
\hline Not answered: & 3 & - & $16.67 \%$ & - \\
\hline
\end{tabular}




\section{Question 9}

Open-air museums have a responsibility towards preserving the build heritage

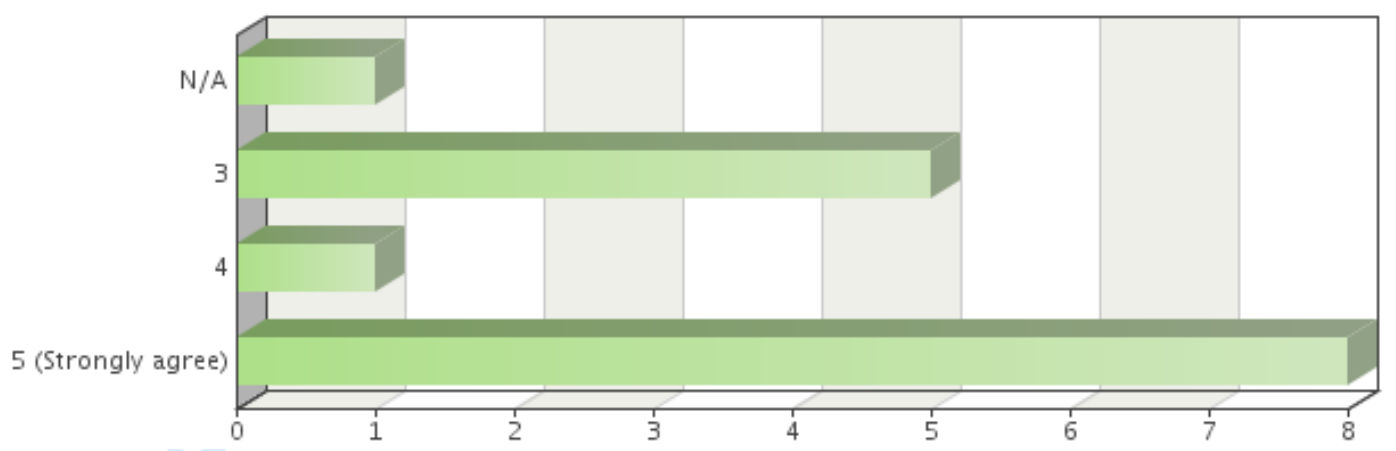

Frequency table

\begin{tabular}{lll}
\hline Levels & $\begin{array}{l}\text { Adjusted } \\
\text { frequency }\end{array}$ & $\begin{array}{l}\text { Relative } \\
\text { frequency } \\
\text { relative } \\
\text { frequency }\end{array}$ \\
\hline N/A & 1 & $5.56 \%$ \\
3 & $6.67 \%$ & $33.33 \%$ \\
4 & 5 & $27.78 \%$ \\
5 (Strongly agree) & 1 & $5.56 \%$ \\
\hline Sum: & $8.67 \%$ & $44.44 \%$ \\
\hline Not answered: & $53.33 \%$ \\
\hline
\end{tabular}




\section{Question 10}

Open-air museums have a responsibility towards preserving building crafts

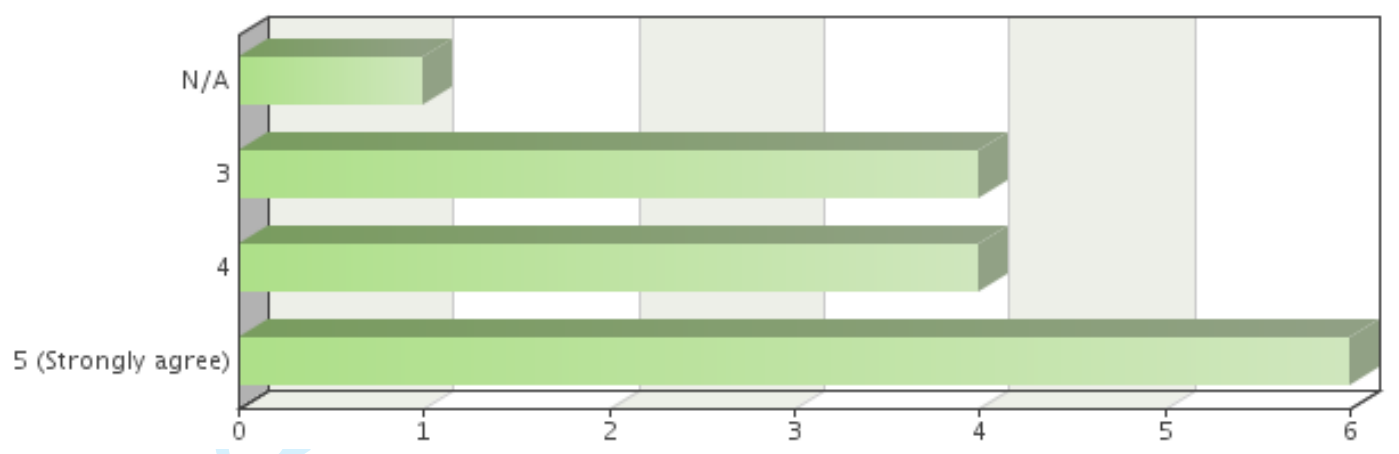

Frequency table

\begin{tabular}{llll}
\hline Levels & $\begin{array}{c}\text { Absolute } \\
\text { frequency }\end{array}$ & $\begin{array}{c}\text { Relative } \\
\text { frequency }\end{array}$ & $\begin{array}{c}\text { Adjusted } \\
\text { relative } \\
\text { frequency }\end{array}$ \\
\hline N/A & 1 & $5.56 \%$ & $6.67 \%$ \\
3 & 4 & $22.22 \%$ & $26.67 \%$ \\
4 & 4 & $22.22 \%$ & $26.67 \%$ \\
5 (Strongly agree) & 6 & $33.33 \%$ & $40 \%$ \\
\hline Sum: & 15 & $83.33 \%$ & $100 \%$ \\
\hline Not answered: & 3 & $16.67 \%$ & - \\
\hline
\end{tabular}




\section{Question 11}

Open-air museums have a responsibility towards preserving crafts

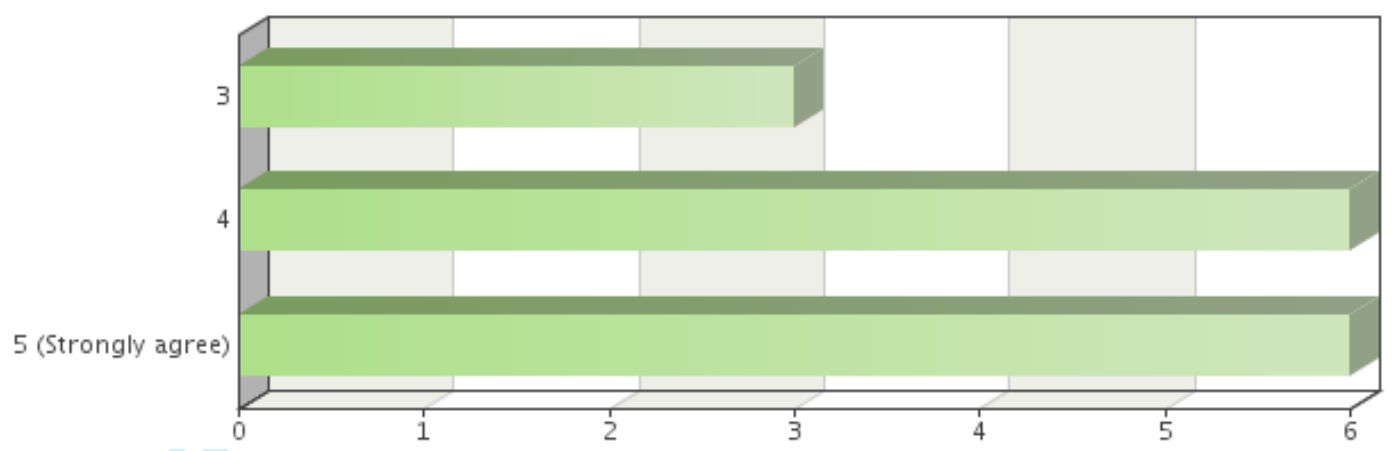

Frequency table

\begin{tabular}{|c|c|c|c|}
\hline Levels & $\begin{array}{l}\text { Absolute } \\
\text { frequency }\end{array}$ & $\begin{array}{l}\text { Relative } \\
\text { frequency }\end{array}$ & $\begin{array}{l}\text { Adjusted } \\
\text { relative } \\
\text { frequency }\end{array}$ \\
\hline 3 & 3 & $16.67 \%$ & $20 \%$ \\
\hline 4 & 6 & $33.33 \%$ & $40 \%$ \\
\hline 5 (Strongly agree) & 6 & $33.33 \%$ & $40 \%$ \\
\hline Sum: & 15 & $83.33 \%$ & $100 \%$ \\
\hline Not answered: & 3 & $16.67 \%$ & - \\
\hline
\end{tabular}




\section{Question 12}

Open-air museums have a responsibility to act as a resource for their local community

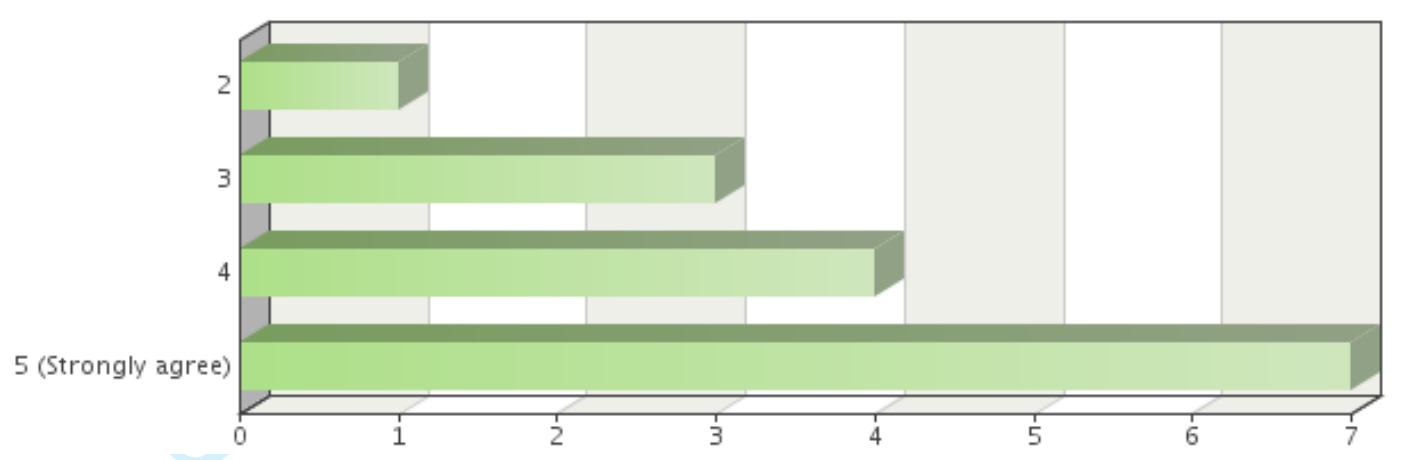

Frequency table

\begin{tabular}{|c|c|c|c|}
\hline Levels & $\begin{array}{l}\text { Absolute } \\
\text { frequency }\end{array}$ & $\begin{array}{l}\text { Relative } \\
\text { frequency }\end{array}$ & $\begin{array}{l}\text { Adjusted } \\
\text { relative } \\
\text { frequency }\end{array}$ \\
\hline 2 & 1 & $5.56 \%$ & $6.67 \%$ \\
\hline 3 & 3 & $16.67 \%$ & $20 \%$ \\
\hline 4 & 4 & $22.22 \%$ & $26.67 \%$ \\
\hline 5 (Strongly agree) & 7 & $38.89 \%$ & $46.67 \%$ \\
\hline Sum: & 15 & $83.33 \%$ & $100 \%$ \\
\hline Not answered: & 3 & $16.67 \%$ & - \\
\hline
\end{tabular}




\section{Question 13}

My museum has had success with integrating crafts into the mediation model. With mediation is referred to the particular approach to teaching and engaging the visitor, which the open-air museums employ.

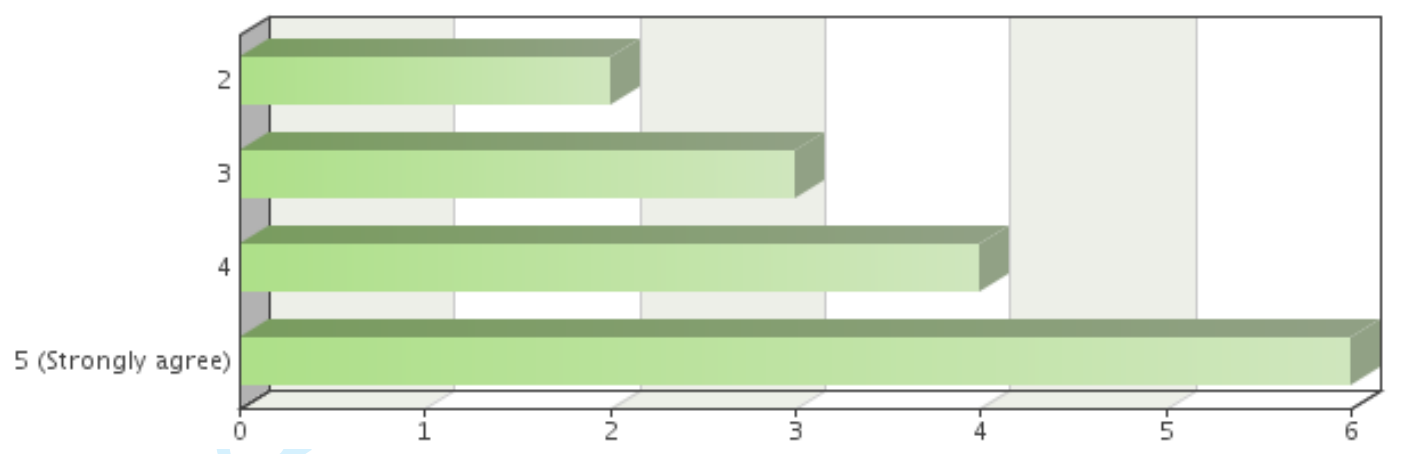

Frequency table

\begin{tabular}{llll}
\hline Levels & $\begin{array}{c}\text { Absolute } \\
\text { frequency }\end{array}$ & $\begin{array}{l}\text { Relative } \\
\text { frequency }\end{array}$ & $\begin{array}{l}\text { Adjusted } \\
\text { relative } \\
\text { frequency }\end{array}$ \\
\hline 2 & 2 & $11.11 \%$ & $13.33 \%$ \\
3 & 3 & $16.67 \%$ & $20 \%$ \\
4 & 4 & $22.22 \%$ & $26.67 \%$ \\
5 (Strongly agree) & 6 & $33.33 \%$ & $40 \%$ \\
\hline Sum: & 15 & $83.33 \%$ & $100 \%$ \\
\hline Not answered: & 3 & $16.67 \%$ & - \\
\hline
\end{tabular}




\section{Question 14}

Crafts and craft professionals have benefited from projects with my museums

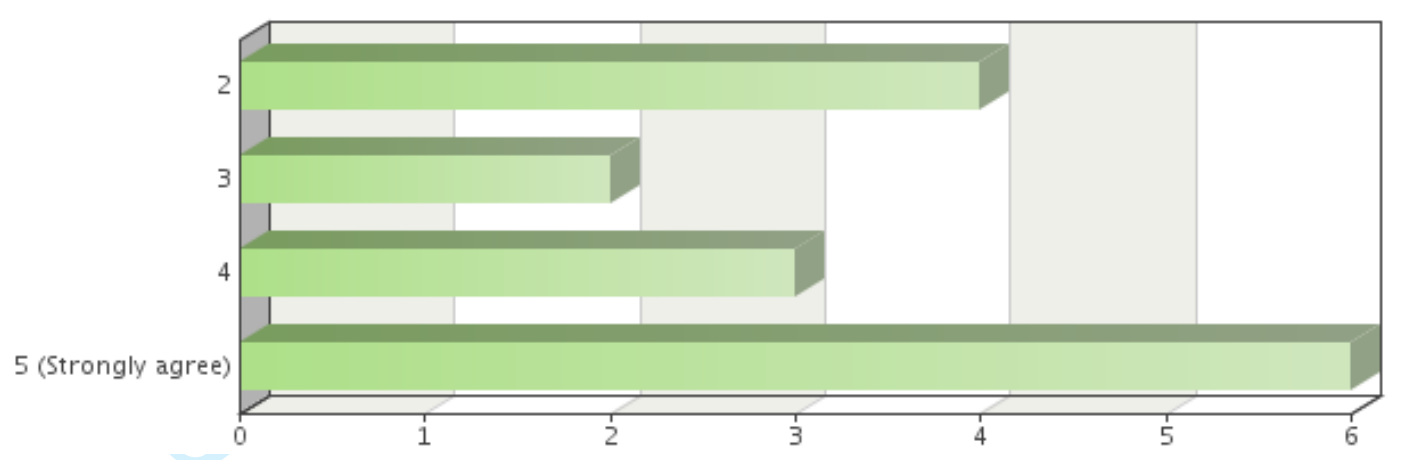

Frequency table

\begin{tabular}{|c|c|c|c|}
\hline Levels & $\begin{array}{l}\text { Absolute } \\
\text { frequency }\end{array}$ & $\begin{array}{l}\text { Relative } \\
\text { frequency }\end{array}$ & $\begin{array}{l}\text { Adjusted } \\
\text { relative } \\
\text { frequency }\end{array}$ \\
\hline 2 & 4 & $22.22 \%$ & $26.67 \%$ \\
\hline 3 & 2 & $11.11 \%$ & $13.33 \%$ \\
\hline 4 & 3 & $16.67 \%$ & $20 \%$ \\
\hline 5 (Strongly agree) & 6 & $33.33 \%$ & $40 \%$ \\
\hline Sum: & 15 & $83.33 \%$ & $100 \%$ \\
\hline Not answered: & 3 & $16.67 \%$ & - \\
\hline
\end{tabular}




\section{Question 15}

Open-air museums could benefit from further developing integration of crafts into their model

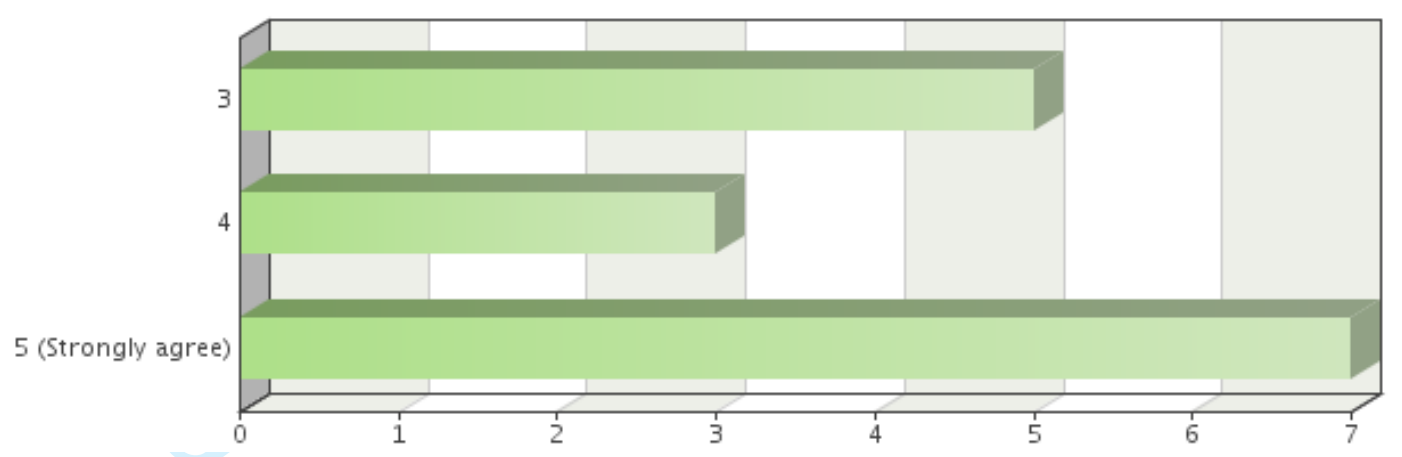

Frequency table

\begin{tabular}{|c|c|c|c|}
\hline Levels & $\begin{array}{l}\text { Absolute } \\
\text { frequency }\end{array}$ & $\begin{array}{l}\text { Relative } \\
\text { frequency }\end{array}$ & $\begin{array}{l}\text { Adjusted } \\
\text { relative } \\
\text { frequency }\end{array}$ \\
\hline 3 & 5 & $27.78 \%$ & $33.33 \%$ \\
\hline 4 & 3 & $16.67 \%$ & $20 \%$ \\
\hline 5 (Strongly agree) & 7 & $38.89 \%$ & $46.67 \%$ \\
\hline Sum: & 15 & $83.33 \%$ & $100 \%$ \\
\hline Not answered: & 3 & $16.67 \%$ & - \\
\hline
\end{tabular}




\section{Question 16}

Open-air museums could benefit from further developing their active visitor approach

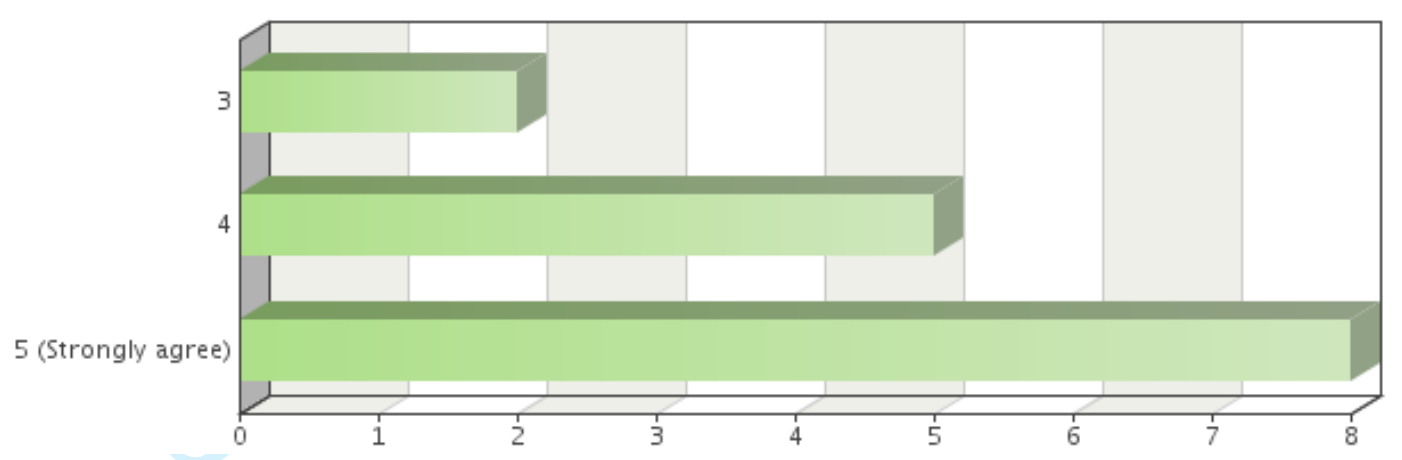

Frequency table

\begin{tabular}{|c|c|c|c|}
\hline Levels & $\begin{array}{l}\text { Absolute } \\
\text { frequency }\end{array}$ & $\begin{array}{l}\text { Relative } \\
\text { frequency }\end{array}$ & $\begin{array}{l}\text { Adjusted } \\
\text { relative } \\
\text { frequency }\end{array}$ \\
\hline 3 & 2 & $11.11 \%$ & $13.33 \%$ \\
\hline 4 & 5 & $27.78 \%$ & $33.33 \%$ \\
\hline 5 (Strongly agree) & 8 & $44.44 \%$ & $53.33 \%$ \\
\hline Sum: & 15 & $83.33 \%$ & $100 \%$ \\
\hline Not answered: & 3 & $16.67 \%$ & - \\
\hline
\end{tabular}




\section{Question 17}

Open-air museums and their local community could benefit from further developing the integration of crafts into the museums daily management

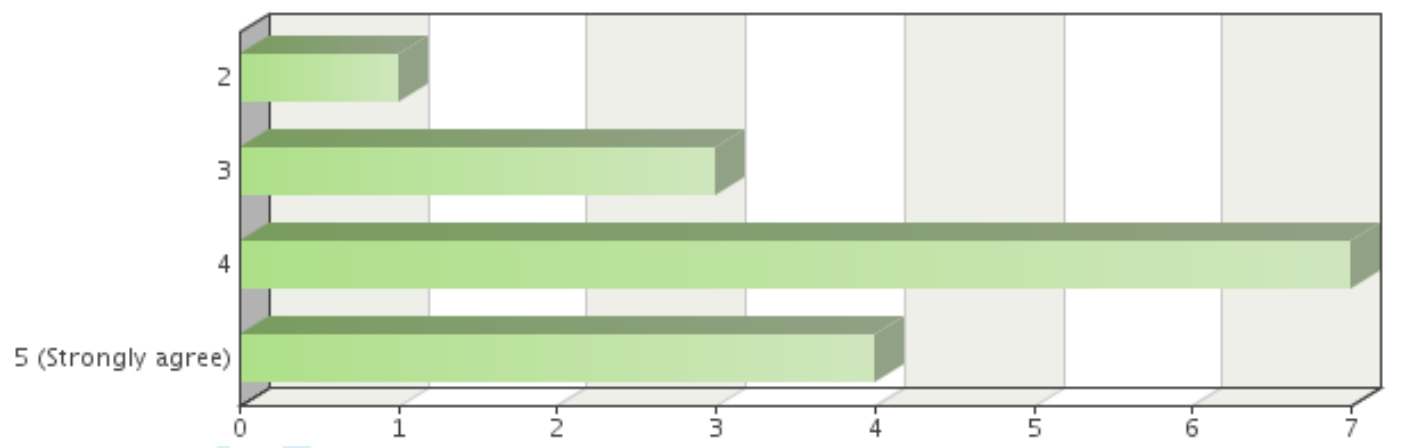

Frequency table

\begin{tabular}{llll}
\hline Levels & $\begin{array}{c}\text { Absolute } \\
\text { frequency }\end{array}$ & $\begin{array}{l}\text { Relative } \\
\text { frequency }\end{array}$ & $\begin{array}{c}\text { Adjusted } \\
\text { relative } \\
\text { frequency }\end{array}$ \\
\hline 2 & 1 & $5.56 \%$ & $6.67 \%$ \\
3 & 3 & $16.67 \%$ & $20 \%$ \\
4 & 7 & $38.89 \%$ & $46.67 \%$ \\
5 (Strongly agree) & 4 & $22.22 \%$ & $26.67 \%$ \\
\hline Sum: & 15 & $83.33 \%$ & $100 \%$ \\
\hline Not answered: & 3 & $16.67 \%$ & - \\
\hline
\end{tabular}




\section{Question 18}

If you would be interested in further participating in this research it would be much appreciated!

Please indicate the preferred email or telephone number where you can be contacted. Thank you very much! 